\title{
DARI BENCANA ALAM, MENEGAKKAN HAK PERIKEMANUSIAAN DALAM KEBINEKAAN (Perspektif HAM dan Islam)
}

\section{Oleh: Dwi Ari Kurniawati \\ Dosen Fakultas Agama Islam Universitas Islam Malang}

Email :dwiaribhakti@gmail.com

\begin{abstract}
Abstrak
Di negara atau bangsa manapun di muka bumi, bisa dipastikan pernah diuji dengan bencana alam. Indonesia merupakan salah stau Negara yang sering menghadapi masalah bencana alam. Keragaman atau kebinekaan manusia Indonesia merupakan realitas kekayaan tersendiri bangsa ini, sehingga ketika terjadi bencana alam, bisa disebut kalau subyek yang menjadi korban juga beragam. Kondisi demikian seharusnya menuntut setiap subyek kehidupan bermasyarakat dan bernegara untuk menjalankan kewajiban kemanusiaannya tanpa membedakan asal-usul etnis, agama, budaya, politik dan lain sebagainya. Semua warga masyarakat mempunyai kewajiban untuk memanusiakan semuanya.
\end{abstract}

Kata kunci: kemanusiaan, hak, Islam, bencana alam

\section{Abstract}

In any country or nation on earth, we can be sure that we have been tested with natural disasters. Indonesia is one of the countries that often face natural disasters. The diversity or diversity of Indonesian people is the reality of the nation's own wealth, so that when natural disasters occur, it can be said that the subjects who are victims also vary. Such conditions should demand every subject of community and state life to carry out their humanitarian obligations without distinguishing the origin of ethnicity, religion, culture, politics and so forth. All citizens have an obligation to humanize all of them.

Keywords: humanity, rights, Islam, natural disasters

\section{PENDAHULUAN}

"Jika Anda membuat seseorang bahagia hari ini, Anda juga membuat dia berbahagia dua puluh tahun lagi, saat ia mengenang peristiwa itu" (Sydney Smith). ${ }^{1}$ Pernyataan ini sebagai suatu ajakan agar setiap subyek dalam kehidupan di dunia ini saling melakukan aktifitas yang bertujuan membahagiakan sesamanya.

1 Abdillah Sunandar, Strategi Membentuk Manusia Inovatif (Jakarta: Sumber Pengetahuan, 2011), 2. 
Smith menuntut setiap subyek supaya tidak pasip saat tedapat kondisi memprihatinkan yang menimpa sesamanya. Setiap individu mempunyai kewajiban untuk aktif dalam memberikan kebahagiaan secara maksimal pada sesamanya. Setiap individu juga mempunyai hak asasi (HAM) yang membutuhkan implementasi dari kewajiban asasi. ${ }^{2}$ Kebahagiaan orang lain merupakan hasil dari kinerja kemanusiaan yang dilakukan sesamanya.

Permasalahan di tengah kehidupan bermasyarakat dan bernegara ini ternyata tidak sedikit. Suatu komunitas yang semula menikmati kedamaian dan keharmonisan, namun tiba-tiba datang bencana alam yang merusak kondisi itu. Mereka akhirnya menjadi komunitas yang terusir dari wilayah yang menjadi tempat tinggalnya. Bencana telah membuatnya menjadi manusia yang kehilangan banyak keberdayaannya. Hidupnya bisa jadi menghadapi beragam keprihatinan kemanusiaannya. ${ }^{3}$

Problem dapat dijumpai dimanapun seseorang berada. Misalnya di Indonesia ini, sejumlah daerahnya sering sekali menghadapi bencana alam. Bencana ini bahkan menjadi kejadian rutin, bukan hanya setahun sekali, tetapi sampai beberapa kali. Masyarakat yang tinggal di lokasi bencana sampai hafal mengenai waktu-waktu datangnya bencana.

Sebagai refleksi, ada beberapa daerah saat ditimpa bencana alam mengakibatkan kondisinya memprihatinkan. Bukan hanya arus lalu lintas kehidupan yang terganggu, banyak kerugian lain yang juga diderita masyarakat akibat bencana. Ada diantara bencana alam yang sampai mengakibatkan kondisi masyarakat hancur berantakan.

Pelajaran dari berkali-kali dan berbagai bentuk bencana itu seharusnya membuat kita banyak belajar, namun faktanya kita tidak mau belajar memahami "pesan" moral kemanusiaan dari bencana itu. Kita tidak atau kurang berusaha sungguh-sungguh untuk menegakkan komitmen mulia dari setiap bencana yang terjadi. Kita bahkan sering mengulangi berbagai sikap dan perilaku yang berhubungan dengan terjadinya bencana, atau kita masih saja tidak peduli terhadap sisi lain dari komitmen kemanusiaan atas terjadinya bencana. ${ }^{4}$

Menurut United Nations International Stategy for Disaster Reduction (UNISDR; Badan PBB untuk Strategi Internasional Pengurangan Risiko Bencana), bahwa Indonesia merupakan negara yang paling rawan (rentan) bencana alam di dunia. Berbagai bencana alam mulai gempa bumi, tsunami, letusan gunung berapi, banjir, tanah longsor, kekeringan, dan kebakaran

\footnotetext{
${ }^{2}$ Basri Hakam, HAM, (Jakarta: Karya Utama Media, 2009), 3.

${ }^{3}$ Abdillah Sunandar, Op.Cit, 3.

${ }^{4}$ Mahmudah Hasan, Bencana dan Kedaulatan Arogansi Manusia, 13 Mei 2013. Diselenggarakan Forum Kajian Kerakyatan dan Kemanusiaan (FK3), Surabaya, 1
} 


\section{PENDIDIKAN MULTIKULTURAL}

hutan rawan terjadi di Indonesia. Bahkan untuk beberapa jenis bencana alam, Indonesia menduduki peringkat pertama dalam paparan terhadap penduduk atau jumlah manusia yang menjadi korban meninggal akibat bencana alam. Kondisi demikian inilah yang menempatkan Indonesia sebagai negara dengan resiko dan dampak bencana alam tertinggi di dunia.

Dari berbagai jenis bencana alam, United Nations International Stategy for Disaster Reduction (UNISDR) merangking jumlah korban pada 6 jenis bencana alam yang meliputi tsunami, tanah longsor, banjir, gempa bumi, angin topan, dan kekeringan. Sedangkan dari keenam jenis bencana alam tersebut, Indonesia menduduki peringkat pertama pada dua bencana alam yakni tsunami dan tanah longsor, peringkat ketiga pada gempa bumi, dan peringkat keenam pada banjir. Hanya di dua bencana alam yakni kekeringan dan angin topan, Indonesia 'absen'.

Seseorang atau sejumlah orang umumnya memahami persoalan bencana dan jenisnya, padahal seharusnya yang perlu dipikirkan adalah tentang bagaimana seharusnya setiap subyek berusaha menunjukkan sikap dan perilaku yang berpola penegakan hak-hak pemanusiaan terhadap korban di segala keragamannya, bukan memilih korban tertentu.

\section{PEMBAHASAN}

\section{Memahami Akar Bencana}

Memahami esensi bencana jelas tidak membacanya semata dari sudut bentuknya bencana, karena ada banyak dimensi yang berhubungan dengan terjadinya bencana alam. Bencana ini berhubungan dengan manusia, sehingga untuk memahaminya, haruslah dengan cara, diantaranya memahami segala aspek yang berhubungan dengan manusia.

Problem dampak bencana pun berhubungan dengan peran kekhalifahan manusia. Tidak boleh terjadi, bahwa ketika bencana menimpa suatu masyarakat, lantas masyarakat ini saja yang dituntut belajar, karena bencana alam merupakan ujian kewajiban asasi bagi setiap orang, baik yang terkena bencana maupun yang tidak terkena bencana alam.

Dalam pemahaman Malik Madani, ${ }^{6}$ jika diteliti ayat-ayat Al-Quran yang berbicara tentang musibah, atau bencana, maka dapat dipahami adanya beberapa bentuk musibah. Pertama, musibah atau bencana yang merupakan hukuman atau siksaan dari Allah Swt. karena kemaksiatan (kezaliman) yang dilakukan sekelompok manusia. Hal ini dinyatakan oleh Allah dalam al-

${ }^{5}$ https://id-id.facebook.com/ForumHijauIndonesia/posts/331818053575965, akses 15 Januari 2018.

${ }^{6}$ Malik Madani. 1997. "Memahami Musibah dan Amanah: Kajian atas Surah alAnfal”. dalam Moh. Mahfud MD dkk. (Ed.). Spiritualitas Alquran dalam Membangun Kearifan Umat. Yogyakarta: LPPAI UII, hal. 162-165. 
Quran: "Dan peliharalah dirimu daripada siksaan yang tidak khusus menimpa orang-orang yang zalim saja di antara kamu. Dan ketahuilah bahwa Allah amat keras siksaan-Nya." (QS. al-Anfal (8): 25). ${ }^{7}$

Ayat di atas menjelaskan bahwa musibah atau bencana yang diberikan oleh Allah tidak hanya kepada orang-orang yang berbuat aniaya atau berdosa saja, tetapi juga kepada orang-orang yang baik. Dengan kata lain, karena perbuatan zhalim dari orang-orang tertentu, semua orang merasakan akibat buruknya. Musibah atau bencana ini tidak hanya menimpa orang yang melakukan kemaksiatan atau kejahatan saja, melainkan menimpa semua manusia secara merata, tanpa pilih kasih, meskipun di dalamnya terdapat orang-orang yang shalih. ${ }^{8}$ Manusia yang berbuat dan menyebarkan kejahatan, termasuk melanggar HAM dimana-mana akan mendapatkan bencana, sekecil atau seberat apapun bencana itu. Adapun manusia yang mengabaikan korban bencana, juga digolongkan sebagai pelanggar $\mathrm{HAM}^{9}$

Dalam salat satu hadis, Nabi Muhammad Saw. bersabda, 'Tidak ada suatu kaum yang melakukan kemaksiatan sedangkan di antara mereka terdapat orang yang mampu mengingkari dan melarang mereka tetapi ia tidak berbuat sesuatu, kecuali taklama lagi Allah akan menimpakan azab dari sisiNya kepada mereka secara merata." (HR. Ahmad). Hadits ini menekankan adanya sekelompok orang yang melakukan tugas amar ma'ruf nahi munkar di tengah-tengah masyarakat yang sudah rusak. Tanpa adanya orang-orang seperti itu, kesalehan individu tidak dapat menjamin keselamatan seseorang dari bencana hukuman Allah Swt. Kedua, musibah atau bencana yang merupakan hukuman dan laknat dari Allah kepada orangorang yang kufur terhadap nikmatNya. Hal ini ditegaskan oleh Allah Swt dalam al-Quran dengan firmanNya: "Dan (ingatlah juga), tatkala Tuhanmu memaklumkan: "sesungguhnya jika kamu bersyukur, pasti Kami akan menambah (ni`mat) kepadamu, dan jika kamu mengingkari (ni`mat-Ku), maka sesungguhnya azab-Ku sangat pedih." (QS. Ibrahim (14): 7). Dalam ayat yang lain Allah Swt berfirman "Telah nampak kerusakan di darat dan di laut disebabkan karena perbuatan tangan manusia, supaya Allah merasakan kepada mereka sebahagian dari (akibat) perbuatan mereka, agar mereka kembali (ke jalan yang benar)." (QS. al-Rum (30): 41). ${ }^{10}$ Tangan manusia memang sudah demikian tampak dan mudah terbaca,

${ }^{7}$ Marzuki, Melestarikan Lingkungan Hidup dan Mensikapi Bencana Alam Dalam Perspektif Islam, staff.uny.ac.id/.../Dr.\%20Marzuki,\%20M.Ag_.\%20Me, akses 15 Januari 2018.

${ }^{8}$ Ibid.

${ }^{9}$ Basri Hakam, Op.Cit, 4.

${ }^{10}$ Marzuki, Op,Cit. 


\section{PENDIDIKAN MULTIKULTURAL}

bahwa akibat tangan manusia ini berbagai bentuk kerusakan telah terjadi di muka bumi. Manusia telah menerima resiko yang sangat serius akibat perbuatannya sendiri.

Ayat-ayat di atas dengan tegas menyatakan bahwa karena keingkaran (kufur) manusia atas nikmat Allahlah yang menyebabkan turunnya azab (siksaan) Allah yang sangat memberatkan dan bahwa kerusakan di muka bumi ini juga akibat perbuatan manusia sendiri. Tujuan pokoknya adalah agar manusia sadar akan perbuatannya tersebut sehingga pada akhirnya dia akan kembali lagi kepada Allah, yakni kembali ke jalan yang benar dan selalu bersyukur atas kenikmatan yang selama ini diterimanya dari Allah Swt. ${ }^{11}$ Kembali ke jalan yang benar identik dengan tuntutan etik, bahwa setiap diri manusia yang bisa memikul amanat kemanusiaan di tengah keragaman (kebinekaan) hanyalah sosok manusia yang dalam dirinya punya kemauan besar untuk memedulikan harkat kemanusiaan manusia lainnya. ${ }^{12}$

Kerusakan yang dimaksud dalam ayat tersebut adalah kerusakan yang diakibatkan oleh perbuatan tangan-tangan manusia berupa tindakan maksiat dan kerusakan-kerusakan moral. Kerusakan tersebut bukan sematamata perbuatan buruk manusia saja. Kerusakan itu bisa berupa bermacammacam musibah atau bencana yang terjadi baik di darat maupun di laut (bahkan di udara/angkasa), seperti kemarau panjang (kekeringan), hujan yang terus menerus sehingga mengakibatkan banjir (seperti di Jakarta), wabah penyakit (seperti flu burung), gempa bumi (seperti di Bantul Yogyakarta), tsunami (seperti yang terjadi Aceh dan Pangandaran), kecelakaan di laut, di darat, maupun di udara, dan lain sebagainya. Kerusakan-kerusakan tersebut dapat merugikan manusia dalam berbagai aspek, baik jiwa (nyawa), harta, binatang, lingkungan, dan mungkin juga moralnya. ${ }^{13}$

Allah tidak bermaksud menyiksa manusia dengan kerusakankerusakan tersebut, sebab jika Allah menghukum manusia dengan cara tersebut pasti akan hancur seluruh manusia di muka bumi ini. Allah Swt berfirman: "Jikalau Allah menghukum manusia karena kezalimannya, niscaya tidak akan ditinggalkan-Nya di muka bumi sesuatu pun dari makhluk yang melata, tetapi Allah menangguhkan mereka sampai kepada waktu yang ditentukan" (QS. al-Nahl (16): 61). Allah menjadikan kerusakan-kerusakan itu dengan maksud agar manusia merasakan akibat perbuatannya sendiri sehingga sadar dan kembali ke jalan yang benar. Orang yang menyadari akan perbuatan-perbuatannya yang salah, dia akan

\footnotetext{
${ }^{11}$ Ibid.

${ }^{12}$ Mahmudah Hasan, Op. Cit, 2.

${ }^{13}$ Marzuki, Op.Cit.
} 
bertaubat untuk tidak mengulanginya dan berusaha untuk melakukan perbuatan yang baik. ${ }^{14}$

Di samping itu, dengan berbagai kejadian itu, Allah juga bermaksud memaafkan sebagian besar dari kesalahan manusia dengan segala karunia dan rahmat-Nya. Karena itu, Allah mengakhiri ayat tersebut dengan pernyataan-Nya, "agar mereka kembali (ke jalan yang benar)". Bisa juga Allah menjadikan itu semua sebagai pelajaran yang berharga bagi manusia dan peringatan atas kelalaiannya sendiri. Ketiga, Musibah atau bencana yang diberikan Allah kepada manusia untuk menguji kualitas keimanan mereka, bukan untuk menghukum dan menunjukkan kemurkaanNya. Musibah semacam ini ditegaskan dalam beberapa ayat al-Quran, di antaranya adalah firman Allah Swt.: "Apakah manusia itu mengira bahwa mereka dibiarkan (saja) mengatakan: "Kami telah beriman", sedang mereka tidak diuji lagi?"Dan sesungguhnya Kami telah menguji orangorang yang sebelum mereka, maka sesungguhnya Allah mengetahui orangorang yang benar dan sesungguhnya Dia mengetahui orang-orang yang dusta." (QS. al-'Ankabut (29): 2-3). ${ }^{15}$ Bencana dalam konteks ini merupakan ujian yang diberikan oleh Allah kepada hambaNya. Beragam ujian yang diberikanNya bisa saja disesuaikan (diadaptasikan) dengan diri setiap orang atau umatnya.

Penempatan negara sebagai akar kriminogen itu logis, karena akibat sikap atau ulah negara yang sering menoleransi banyak perilaku melanggar norma yuridis atau HAM, termasuk banjirnya kemaksiatan dan perbuatan korup, negara menjadi kesulitan memproteksi rakyat dari terjadinya bencana dimana-mana.

Hubungan kausalitas antara dosa (pelanggaran HAM) dan bencana, sering disinggung dalam kisah nubuat (kenabian). Dalam Islam misalnya, ada kisah tentang hancurnya Saba', sebuah negeri berlimpah kemakmuran ekonomi yang berubah menjadi melarat dan hancur berantakan karena dosadosa atau kejahatan yang dilakukan dan "dikembangkan" oleh penduduknya.

Ada pula kisah tenggelamnya manusia akibat mengingkari ajaran Nabi Nuh, dan umat Nabi Luth yang dihancur-luluhkan oleh Allah akibat lebih memilih dan bahkan mengabsolutkan berbagai bentuk penyimpangan moral, khususnya dalam kontek hubungan seksual. Peristiwa yang dicatat sejarah ini intinya menyingkap rahasia keterkaitan perbuatan menyimpang dengan bencana atau model perbuatan manusia (masyarakat) yang berakar menghancurkan diri dan keberlanjutan hidupnya.

\footnotetext{
${ }^{14}$ Ibid.

${ }^{15}$ Ibid.
} 
Menurut Syamsul Arifin, bahwa logika dosa-bencana seakan memperoleh kebenaran empiris ketika badai Katrina mengempaskan Mississipi di Amerika Serikat (AS) pada 25 Agustus 2005. AS harus menanggung kerugian sekitar USD 80 miliar atau sekitar 800 triliun. Sebuah majalah berita mingguan yang terbit di Jakarta tidak segan-segan menyebut badai Katrina sebagai karma menyusul ulah tentara AS yang tidak senonoh baik di Penjara Abu Ghraib, Iraq, maupun di Penjara Guantanamo, Kuba. Tentu, kejahatan perang AS sewaktu menginvasi Iraq dianggap pula berkaitan dengan karma yang ditanggung negeri adidaya itu. ${ }^{16}$

Kasus yang pernah menimpa AS itu setidaknya memberi pelajaran pada kita, bahwa bencana alam dalam segala jenisnya bisa menimpa bangsa manapun di muka bumi. Bangsa yang maju di bidang ilmu pengetahuan dan teknologi seperti AS tidak ada jaminan lantas terbebas dari bencana alam. Tuhan bisa mengirimkan atau menguji bangsa manapun yang diinginkannya, apalagi terhadap masyarakat atau bangsa yang suka melakukan berbagai bentuk kejahatan atau pelanggaran HAM.

Khusus di negeri ini, WALHI pernah menyebut, bahwa kita bangsa Indonesia tidak bisa lagi bangga dengan julukan Jamrud Khatulistiwa, karena pada kenyataannya, negeri kita adalah negeri sejuta bencana. Sebutan demikian dapat dijadikan sebagai bahan refleksi, bahwa akar bencana alam bisa bersumber dari setiap manusia Indonesia yang terjerumus dalam berbagai bentuk perbuatan tercela.

\section{Belajar Untuk Menegakkan HAM}

Setiap manusia yang ingin berbuat baik seperti menghadirkan kebahagiaan dan keselamatan bagi sesamanya, terkadang membutuhkan pelajaran dari sejarah, karena dari sejarah ini, terdapat banyak kisah-kisah dari para pendahulu yang mengajarkan tentang bagaimana seharusnya seseorang itu menjalani kehidupan yang benar dan bermartabat, termasuk menghindari berbagai bentuk perbuatan yang merugikan orang lain dan alam semesta.

Salah satu referensi historis yang bisa digunakan belajar membangun komitmen kepemimpinan adalah kepemimpinan Nabi Sulaiman. Dalam model kepemimpinan Nabi Sulaiman ini, banyak terkandung teladan positip yang bisa digunakan membangun negara Indonesia, khususnya untuk menanggulangi bencana. ${ }^{17}$

\footnotetext{
${ }^{16}$ Ghaffar Anwar, Belajar dari Tragedi Dunia, Pustaka Pengetahuan, (Bandung, Rintiskalamuna, 2011), hal. 14.

${ }^{17}$ M. Bashori Muchsin, Belajar dari Sejarah: Syarat Menjadi Manusia yang rahmatan lil alamin, 12 Mei 2013, LPITI Unisma, 1.
} 
Ada kisah menarik dari Nabi Sulaiman. Suatu ketika Nabi Sulaiman mengajak tentaranya untuk berkeliling negeri guna mengetahui keberadaan rakyatnya. Nabi Sulaiman rutin melakukan kunjungan terhadap kehidupan konkrit rakyatnya. Beliau sering melihat dan membaca, serta memahami secara riil masalah yang dihadapi oleh rakyat dan makhluk Tuhan lainnya. Misalnya suatu saat, Raja Semut yang melihat Nabi Sulaiman dan tentaranya berkeliling itu, lantas memerintahkan rakyatnya (warga semut) untuk menyelamatkan dan menghindarkan diri supaya tidak sampai terinjakinjak. "kaumku, segera mencari perlindungan dari tentara Sulaiman", demikian perintah Raja Semut. "Kenapa harus menghindar wahai raja?" tanya semut lagi. "Tentara Sulaiman itu tidak mengetahui kalau ada hewan sekecil kita yang berjalan kesana-kemari, sehingga harus dari kita sendiri yang berusaha mencari selamat", jawab Raja Semut. ${ }^{18}$

Mendengar dialog Raja semut dan rakyatnya itu, Nabi Sulaiman tersenyum dan kemudian memerintahkan kepada tentaranya untuk menjaga kelestarian alam, tidak melakukan perusakan, dan menabur kezaliman kepada makhluk hidup lainnya. Nabi Sulaiman juga memerintahkan supaya manusia (pengikutnya) selalu membaca dan berdialektika dengan sesama makhluk Tuhan, bahwa yang butuh hidup, tumbuh, berkembang, dan keselamatan bukan hanya manusia, tetapi juga hutan dan hewan. ${ }^{19}$

Salah satu hewan yang butuh perlindungan adalah semut. Jika dikaji dari sudut filosofisnya, semut merupakan gambaran dari hewan terkecil, yang tentu saja secara alamiah berada dalam kerentanan ketika harus berhadapan dengan hewan-hewan lainnya yang lebih besar, apalagi dengan makhluk bernama manusia yang dikaruniai kelebihan akal dan fisik. Dari segi kemampuan akal saja misalnya, manusia bisa merekayasa hewan (semut) untuk dibakar atau dikorbankan, sementara kalau semut terbatas hanya "menggigit" atau sedikit melukai manusia. ${ }^{20}$

Sebagai makhluk terkecil saja, semut butuh tempat untuk hidup, melestarikan keturunan, dan menikmati karunia Tuhan. Guna mewujudkan cita-citanya ini, semut lebih sering mengambil keputusan menyelamatkan atau melindungi "hak asasinya" dari kemungkinan bahaya pelanggaran yang dilakukan pihak lain seperti manusia yang berkecenderungan mengancam dan potensial membunuhnya.

Sekelompok semut itu menilai, bisa jadi tentara Nabi Sulaiman (manusia) misalnya tidak melihat dan mengetahui kalau dibalik goa, rimbunan pohon, semak belukar, dan kawasan hutan, terdapat makhluk hidup lain yang butuh tumbuh berkembang atau menunjukkan

\footnotetext{
${ }^{18}$ Ibid.

${ }^{19}$ Ibid, 1-2.

${ }^{20} \mathrm{Ibid}$,
} 


\section{PENDIDIKAN MULTIKULTURAL}

"eksistensinya", sehingga mereka (semut) mengambil keputusan menghindari "terjangan" kaki-kaki perkasa manusia yang akan melewati kerumunannya. Kaki-kaki perkasa manusia dinilai oleh semut sering tidak mempertimbangkan keberadaan makhluk di sekitarnya, akibatnya memungkinkan makhluk hidup lainnya dapat menjadi korbannya.

Pilihan yang dijatuhkan Raja semut itu selayaknya dijadikan pelajaran berharga bagi setiap manusia, bahwa sekelas semut saja bisa mengevaluasi perilaku manusia yang potensial berbuat alpa dan menyebar kezaliman. Pilihan sebagaimana yang dijatuhkan "warga" hewan seperti semut ini sebagai kritik kepada manusia supaya setiap aktifitas yang dilakukannya selalu diikuti dengan prinsip kehati-hatian, menggunakan nalar sehat, atau dengan pertimbangan obyektif. ${ }^{21}$ Tuhan membuat perumpamaaan supaya manusia memahami esensi kekhalifahannya di muka bumi dalam menegakkan HAM.

Prinsip kehati-hatian hewan kecil itu secara tidak langsung mengandung pesan edukatif atau mengarahkan pada pembelajaran pada manusia supaya menjaga keseimbangan kehidupan dirinya, sesamanya, maupun makhluk hidup lainnya di muka bumi. Hewan kecil ini sebagai cermin "warga gurem" atau komunitas akar rumput (the grass root) yang mengharapkan atau menuntut perlindungannya dari kemungkinan perilaku manusia liar, tak terkontrol, atau rentan berlaku adidang adigung.

Manusia memang harus banyak dan terus belajar. Karena kalau dari aspek itu saja manusia atau para penyelenggara negara gagal menunjukkan keluhuran atau keagungan budinya, bagaimana mungkin manusia bisa menunaikan (menegakkan) tugas yang lebih besar dalam hidupnya yang berelasi dengan amanat publik, seperti menegakkan HAM, jika membentuk diri sebagai sosok bermental demikian tidak mampu.

Kehancuran sumberdaya alam dan semakin punahnya binatangbinatang yang seharusnya berada dalam perlindungan negara, adalah bukti kegagalan manusia dalam mengelola hubungannya dengan Tuhan, sesama manusia, dan alam semesta. Kebakaran hutan yang rutin terjadi di sejumlah Propinsi misalnya meyumbang emisi gas rumah kaca.

Deforestasi tidak terkendali di Indonesia mendudukan Indonesia sebagai negara pencemar terbesar ketiga di dunia Di Indonesia, hutan rawa gambut lenyap akibat pembalakan, pengeringan dan di bakar untuk perluasan kelapa sawit. Lahan gambu ini (kadang-kadang hingga kedalaman 12 meter) menyimpan karbon yang sangat besar. Ketika mereka di

\footnotetext{
${ }^{21}$ Imam Kabul, Membangun Pencerahan Hati, (Jakarta: Nirmana Media, 2006),
} 34. 
keringakn dan di bakar akan menjadi sebuah bom karbon, melepaskan hampir dua milliyar ton karbondioksida berbahaya setiap tahun. ${ }^{22}$

Model manusia perusak atau penghancur lingkungan di negeri ini, khususnya yang jadi elemen fundamental negara lebih sering tidak mau belajar dari aspek terkecil yang menuntut perhatian atau perlindungannya, sehingga ketika manusia berhubungan dengan kepentingan besar yang menuntut tanggungjawabnya, manusia justru mencederainya. Lingkungan yang semestinya dijaga dari kerusakan, justru dirusaknya, sehingga mengakibatkan timbulnya bencana secara terus menerus.

Perilaku manusia yang merusak ekologi itu identic dengan melakukan pelanggaran HAM. Dalam konsideran UU Nomor 39 Tahun 1999 tentang HAM $^{23}$ disebutkan, bahwa manusia, sebagai mahluk ciptaan Tuhan Yang Maha Esa yang mengemban tugas mengelola dan memelihara alam semesta dengan penuh ketaqwaan dan penuh tanggung jawab untuk kesejahteraan umat manusia, oleh pencipta-Nya dianugerahi hak asasi untuk menjamin keberadaan harkat dan martabat kemuliaan dirinya serta keharmonisan lingkungannya.

Dalam huruf b UU HAM itu disebutkan, bahwa hak asasi manusia merupakan hak dasar yang secara kodrati melekat pada diri manusia, bersifat universal dan langgem, oleh karena itu harus dilindungi, dihormati, dipertahankan, dan tidak boleh diabaikan, dikurangi, atau dirampas oleh siapapun.

Pelanggaran seperti itu sudah mendapatkan peringatan dari banyak kalangan, termasuk dari ahli-ahli hukum. Pakar hukum Islam Yusuf alQardlawi menyebut lingkungan sebagai sebuah lingkup di mana manusia hidup, ia tinggal di dalamnya, baik ketika bepergian ataupun mengasingkan diri, sebagai tempat ia kembali, baik dalam keadaan rela atau terpaksa. ${ }^{24}$ Kondisi ekologis merupakan sumberdaya strategis yang harus dijaga oleh manusia. Manusia yang mau menjaganya sama dengan menegakkan hak asasinya sendiri maupun hak asasi sumberdaya lain yang diberikan Tuhan kepadanya.

Tipe manusia demikian itu bukannya menunjukkan peran-peran yang bersahabat dan membangun harmonisasi dengan sumberdaya ekologis, tetapi bercorak merusak dan menghancurkannya. Sumberdaya alam sebagai

\footnotetext{
${ }^{22}$ Rahman Hadi, Negara dalam Hegemoni Destruksi Ekologi, Memperatanyakan Tnggungjawab Negara dalam Melindungi Korban Bencana Alam, 15 Juli 2010, Surabaya, 2 . Manusia

${ }^{23}$ Undang-Undang Republik Indonesia Nomor 39 Tahun 1999 tentang Hak Asasi

${ }^{24}$ Yusuf Al-Qardlawi, Islam Agama Ramah Lingkungan. Terj. oleh Abdullah Hakam Shah dkk. Pustaka Al-Kautsar. Jakarta, 2002, hal. 5.
} 


\section{PENDIDIKAN MULTIKULTURAL}

penyangga besar masyarakat dan bangsa justru diperlakukan menjadi urusan sepele atau dikriminalisasikan dan dikapitalismekannya..

Bilamana hal itu dikaji dari sudut kepentingan semut (dalam kisah Nabi SulaimanO yang memilih menyelamatkan diri dari bahaya yang mengancamnya, semestinya elit negara merasa ditantang untuk menyemaikan gerakan positip yang bercorak mewujudkan perlindungan terhadap makhluk hidup lainnya di muka bumi. Semut menantang elite negeri ini untuk berlaku waspada saat mengayunkan langkah-langkahnya supaya tidak menabur dan menyuburkan (memproduksi) bencana di bumi pertiwi ini.

Kasus berbaga bentuk (berjuta) bencana di negeri ini adalah tidak lepas dari kegagalan manusia dalam mengendalikan kecenderungan keserakahannya. ${ }^{25}$ Manusia yang mengabdi pada keserakahan merupakan sosok pelanggar HAM serius, karena apa yang diperbuatnya bisa menghancurkan sumberdaya keberlanjutan hidup manusia.

Bilamana setiap diri manusia mau menerjemahkan filosofi dialog semut dengan Nabi Sulaimn, tentulah kecenderungan atau keinginan merebut, menginjak, menguasai, dan mengorbankan makhluk hidup di luar dirinya bisa dicegah. Mereka tidak akan melakukan dan mempertahankan sikap arogansi dan kriminalisainya nya dalam mempergauli sesama dan konstruksi sumberdaya ekologis.

Peran manusia yang mau meneladani Nabi Sulaiman akan berpola menyelamatkan, melestarikan, atau mempergauli makhluk hidup lainnya secara memanusiakan, dan bukan menghancurkan. Sebaliknya menjadi berlawanan dengan doktrin Nabi Sulaiman, ketika saat menjadi pejabat atau aparat, mereka tergelincir menjadi perusak atau melakukan dehumanisasi ekologis.

Dalam konsideran UU HAM juga disebutkan, bahwa bangsa Indonesia sebagai anggota Perserikatan Bangsa-Bangsa mengemban tanggung jawab moral dan hukum untuk menjunjung tinggi dan melaksanakan Deklarasi Universitas tentang Hak Asasi Manusia yang ditetapkan oleh Perserikatan Bangsa-Bangsa, serta berbagai instrumen yang telah diterima oleh negara Republik Indonesia;

Hal itu mengandung konsekuensi, bahwa setiap diri yang mau belajar dari berbagai sejarah seperti kasus hewan bernama semut berarti berkeinginan menyelamatkan atau melindungi segala potensi yang disediakan Allah SWT ini untuk kepentingan bersama. Sedangkan manusia yang tidak mau belajar, berarti mendukung terjadi dan maraknya bencana.

\footnotetext{
${ }^{25}$ Mahmudah Hasan, Op.Cit, hal. 3.
} 


\section{PENUTUP}

Di negara atau bangsa manapun di muka bumi, termasuk Indonesia bisa dipastikan pernah diuji dengan bencana alam. Indonesia merupakan salah stau Negara yang sering menghadapi masalah bencana alam. Keragaman atau kebinekaan manusia Indonesia merupakan realitas kekayaan tersendiri bangsa ini, sehingga ketika terjadi bencana alam, bisa disebut kalau subyek yang menjadi korban juga beragam. Bukan hanya manusia yang menjadi korban, tetapi banyak aspek yang berhubungan dengan manusia juga ikut menjadi korbannya. Kondisi ini tidak lepas dari perbuatan manusia yang terjerumus melakukan pelanggaran HAM.

Kondisi demikian itu seharusnya menuntut setiap subyek kehidupan bermasyarakat dan bernegara untuk menjalankan kewajiban kemanusiaannya tanpa membedakan asal-usul etnis, agama, budaya, politik dan lain sebagainya. Semua warga masyarakat mempunyai kewajiban untuk memanusiakan semuanya, termasuk memanusiakan ekologi. Memanusiakan ekologi berarti memartaatkan sumberdaya alam.

\section{DAFTAR PUSTAKA}

\section{Buku}

Abdillah Sunandar, 2011, Strategi Membentuk Manusia Inovatif Jakarta: Sumber Pengetahuan.

Basri Hakam, 2009, HAM, Jakarta: Karya Utama Media.

Departemen Agama Republik Indonesia, 2002, Al-Qur'an dan Terjemahanya, Jakarta: Departemen Agama Republik Indonesia

Ghaffar Anwar, 2011, Belajar dari Tragedi Dunia, Bandung: Rintiskalamuna.

Imam Kabul, 2006, Membangun Pencerahan Hati, jakarta: Nirmana Media, Malik Madani. 1997. "Memahami Musibah dan Amanah: Kajian atas Surah alAnfal". dalam Moh. Mahfud MD dkk. (Ed.). Spiritualitas Alquran dalam Membangun Kearifan Umat. Yogyakarta: LPPAI UII.

Yusuf Al-Qardlawi, 2002, Islam Agama Ramah Lingkungan. Terj. oleh Abdullah Hakam Shah dkk. Jakarta: Pustaka Al-Kautsar.

\section{Internet dan Makalah}

Https://id-id.facebook.com/ForumHijauIndonesia/posts/331818053575965, akses 15 Januari 2018.

Mahmudah Hasan, 2013, Bencana dan Kedaulatan Arogansi Manusia, Makalah, Surabaya. 
Marzuki, Melestarikan Lingkungan Hidup dan Mensikapi Bencana Alam Dalam

staff.uny.ac.id/.../Dr.\%20Marzuki,\%20M.Ag_.\%20Me, akses 15 Januari 2018.

M. Bashori Muchsin, Belajar dari Sejarah: Syarat Menjadi Manusia yang rahmatan lil alamin, 12 Mei 2013, LPITI Unisma.

Rahman Hadi, Negara dalam Hegemoni Destruksi Ekologi, Memperatanyakan Tnggungjawab Negara dalam Melindungi Korban Bencana Alam, 15 Juli 2010, Surabaya,

\section{Undang-Undang}

Undang-Undang Republik Indonesia Nomor 39 Tahun 1999 tentang Hak Asasi Manusia 